DOI https://doi.org/10.30525/978-9934-26-113-8-21

\title{
МОРФОЛОГІЧНА ПЕРЕБУДОВА СОСОЧКІВ ЯЗИКА ПРИ СТРЕПТОЗОТОЦИНОВОМУ ЦУКРОВОМУ ДІАБЕТІ
}

\author{
Жураківська О. Я. \\ доктор медичних наук, професор, \\ професор кафедри анатомії людини \\ Івано-Франківський наиіональний медичний університет \\ Атаманчук О. В. \\ кандидат медичних наук, \\ доцент кафедри гістологї, ичитології та ембріології \\ Івано-Франківський начіональний медичний університет

\section{Олійник Р. П.} \\ кандидат медичних наук, \\ асистент кафедри стоматології післядипломної освіти \\ Івано-Франківський начіональний медичний університет \\ м. Івано-Франківськ, Украӥна
}

Цукровий діабет (ЦД) $€$ важким ендокринним захворюванням, а його ускладнення 3 боку слизової оболонки ротової порожнини (СОРП) $є$ одними із найбільш розповсюджених захворювань людини [1]. У $80 \%$ випадків пацієнти з ЦД скаржаться на спотворення смаку, дискомфорт, парестезії, печію та болі в язиці [2]. Одним із ускладнень ЦД $є$ хронічний діабетичний глосит, який характеризується наступними симптомами: язик набряклий, покритий білим або жовтуватим сухуватим нальотом, шорсткий, іноді з ділянками гіперкератозу [3]. У патогенезі діабетичного глоситу велику роль відводять імунологічним аспектам процесу деструкції слизової оболонки язика (СОЯ) [45, 47, 54]. Тому метою нашого дослідження було встановити особливості структурної перебудови сосочків язика при стрептозотоциновому цукровому діабеті (СЦД).

Для дослідження використали 10 статевозрілих білих щурів-самців лінії Вістар (масою тіла 180-200 г), які порівну розподілялися на 2 групи: експериментальну, контрольну. Експериментальній групі одноразово внутрішньоочеревинно вводили стрептозотоцин «SIGMA» (CША), який розводили в 0,1 М цитратному буфері $3 \mathrm{pH} 4,5$ (із розрахунку 6 мг на 100 г маси тіла). Контрольній групі в еквівалентній дозі одноразово внутрішньоочеревинно вводили $0,1 \mathrm{M}$ цитратний буфер із $\mathrm{pH} 4,5$. Розвиток СЦД контролювали за рівнем глюкози в крові, яку щоденно 
натще вимірювали в краплі крові $з$ хвостової вени на глюкометрі фірми «Accu-Chec Active» (ФРН). Забір матеріалу здійснювали через 8 тижнів від початку моделювання СЦД після попередньої евтаназії під тіопенталовим наркозом. Використали гістологічний, електронномікроскопічний та статистичний методи дослідження.

Через 8 тижнів від початку моделювання СЦД висота всіх типів ниткоподібних сосочків різко зменшується. На цьому фоні виявляються різко розширені та деформовані смакові пори. Потрібно відмітити також виражену деформацію грибоподібних сосочків, які, як правило, мають скошену в одну сторону поверхню і містять велику кількість мікроорганізмів, переважно їх кокові форми. На поверхні СОЯ виявляється велика кількість пластинчастих структур і кератинових конгломератів. Особливо чітко ці структури спостерігаються на вершинах ниткоподібних і валкуватих сосочків. На окремих ділянках вся поверхня сосочків вкрита дрібноглобулярними структурами, що робить їх подібними до плодів шовковиці. Морфологічні зміни СОЯ характеризуються різноманітним поєднанням атрофічних і гіперпластичних процесів, внаслідок чого багатошаровий плоский епітелій нерівномірно потовщується. Спостерігаються виражені дистрофічні зміни епітеліоцитів рогового шару (дискератоз, паракератоз). У всіх ділянках СОЯ виявляється картина запалення. Розмір остистих клітин збільшується, а їх міжклітинний простір зменшується. Епітеліальні вирости досягають великого розміру і різноманітної форми. Змінюється процес зроговіння епітелію СОЯ. Виникають структурні зміни епітеліальних клітин: вакуолізація цитоплазми, пікноз, цитоліз, оголення ядра, каріорексис, двоядерність. Окремі автори [5] у підслизовому шарі спостерігали скупчення жирової тканини, яка, на їхню думку, є специфічною ознакою ЦД.

Таким чином, морфологічні зміни СОЯ при СЦД характеризуються різноманітним поєднанням атрофічних i гіперпластичних процесів, внаслідок чого багатошаровий плоский епітелій нерівномірно потовщується. Спостерігаються виражені дистрофічні зміни епітеліоцитів рогового шару (дискератоз, паракератоз) в ділянці смакових цибулин. У всіх ділянках СОЯ виявляється картина запалення, що вказує на розвиток діабетичного глоситу.

\section{Література:}

1. Акмаев И. Г. Нейроиммуноэндокринные аспекты патогенеза сахарного диабета. Сахарный диабет. 2015. № 3. С. 8-12.

2. Фомина Е .И., Пожарицкая М. М., Давыдов А. Л. и др. Нарушения вкусового восприятия у больных сахарным диабетом 2-го типа. Клиницист. 2007. № 1. С. 20-24.

3. Сон И. М., Дычко Е. Н., Ковач И. В. Характер микроциркуляции в полости рта при глоссалгии. Украӥнський стоматологічний альманах. 2012. T. 1, № 2. C. 23-31. 
4. Byrd J. A., Bruce A. J., Rogers R. S. Glossitis and other tongue disorders. Dermatol. Clin. 2003. Vol. 21, № 1. P. 123-134

5. Stähler F., Brennick M.J., Delikatny J. Tongue Fat Infiltration in Obese Versus Lean Zucker Rats. Sleep. 2014. Vol. 37, № 6. P. 1095-1102.

DOI https://doi.org/10.30525/978-9934-26-113-8-22

\title{
КРАНІОМЕТРІЯ ЧЕРЕПА ТА ЛИЦЯ ПЛОДІВ І НОВОНАРОДЖЕНИХ
}

\author{
Костюк В. О.
}

аспірант кафедри анатомії, клінічної анатомії та оперативної хірургї

Буковинський державний медичний університет

\section{Слободян О. М.}

доктор медичних наук, професор,

завідувач кафедри анатомії, клінічної анатомії та оперативної хірургіі

Буковинський державний медичний університет

Лаврів Л. П.

кандидат медичних наук,

старший викладач кафедри анатомії, клінічної анатомії та

оперативної хірургії

Буковинський державний медичний університет

\section{Столяр Д. Б.}

кандидат медичних наук,

асистент кафедри гістології, ичтологї̈ та ембріології

Буковинський державний медичний університет

\section{Березина-Дундюк С. I.}

аспірант кафедри анатомії, клінічної анатомії та оперативної хірураї Буковинський державний медичний університет

$$
\text { м. Чернівиі, Україна }
$$

Розвиток нових методів дослідження, таких як ультразвукові та рентгенологічні методи (магнітно-резонансної томографії), формує поняття ультразвукової та рентгенологічної норми на різних етапах розвитку людини [1-5]. Важливе значення має прогнозування стану 